Pak. j. sci. ind. res. Ser. B: biol. sci. 201154 (3) 167-171

\title{
The Effect of Preservation Methods on the Nutritional Quality of Fluted Pumpkin (Telfairia occidentalis) Leaves
}

\author{
Fred Omon Joseph Oboh* and Osayuwamen Aigbe \\ Department of Basic Sciences, Benson Idahosa University, PMB 1100, Benin City, Nigeria
}

(received July 8, 2010; revised July 26, 2011; accepted August 4, 2011)

\begin{abstract}
The present research was undertaken to investigate the effect of various blanching and drying treatments on the vitamin $\mathrm{C}, \beta$-carotene, iron, protein content and drying time of fluted pumpkin (Telfairia occidentalis Hook) leaves. The leaves were subjected to sun or oven drying alone or after blanching in boiling water, dilute citric acid $(0.3 \%)$ or dilute potassium meta-bisulphite $(0.5 \%)$. In the absence of blanching pre-treatment, oven drying resulted in shorter drying time for the leaves and a higher vitamin $\mathrm{C}$ content of the dried product than sun drying and there was no significant difference $(\mathrm{p}>0.01)$ between the protein, $\beta$-carotene and iron content of the oven and sun dried products. Leaves blanched in boiling water, dilute citric acid, or dilute potassium meta-bisulphite solution, followed by sun or oven drying had less vitamin $C$, iron, protein and $\beta$-carotene than leaves dried without blanching. Compared with the use of boiling water, blanching in boiling potassium meta-bisulphite reduced the loss of $\beta$-carotene, protein and iron; blanching in dilute citric acid reduced the loss of iron. Except for citric acid pre-treatment, blanching prior to drying shortened drying time.
\end{abstract}

Keywords: fluted pumpkin leaves, blanching, citric acid, potassium metabisulphite, drying, nutrients

\section{Introduction}

Green leafy vegetables are a good source of dietary fibre, carotenoids, vitamin $\mathrm{C}$, folate, phytochemicals and certain minerals, but have low lipid, carbohydrate and protein concentration (Wills et al., 1998). They present an inexpensive and readily available approach to combating certain micronutrient deficiencies. Due to their high moisture and adequate fibre content they provide bulk in the diet and give a feeling of satiety, in the absence of energy dense dietary components. They are helpful for the prevention and management of some chronic conditions that arise partly as a result of excessive energy and inadequate fibre intake. Their phytochemicals also offer protection against disease (Wardlaw and Kessel, 2002).

The plant Telfairia occidentalis Hook, commonly known as fluted pumpkin, oyster nut or ridge gourd belongs to the Cucurbitaceae family. It is indigenous to West Africa, but is found wild or cultivated in West, Central, East and Southern Africa (Bosch et al., 2005). Its primary use is as a source of edible leafy vegetable. Secondary uses of the plant are for forage (leaves), as medicine (leaves and roots), as a source of vegetable oil and condiment (seeds), and for fibre (vine) (Bosch et al., 2005).

*Author for correspondence; E-mail: fredoboh67@yahoo.co.uk
Leafy vegetables are highly susceptible to deterioration after harvesting, resulting in heavy post harvest losses. Drying of foodstuffs is an old method for food preservation. Although widespread, cheap and reliable, drying also changes product quality, texture and nutritive value. These changes can be mitigated, however by adequate preparation and pre-treatment before drying. Blanching or scalding in hot water or steam makes the product tender, limits discolouration, eliminates intracellular gases responsible for oxidation reactions, kills harmful bacteria and deactivates enzymes which disintegrate the tissues. Blanching in boiling water makes it possible to incorporate, simultaneously, citric acid and/or sulphur as potassium meta-bisulphite (Rozis, 1997). Blanching and other thermal treatment of green leaves can also enhance the bioavailability of micronutrients by destroying antinutrients and by releasing micronutrients from entrapment in the plant matrix (Hotz and Gibson, 2007; Yang and Tson, 2006; Yadev and Sehgel, 2002; Yeum and Russel, 2002; Henry and Massey, 2001; Rodriguez-Amaya, 1997). Thin-slicing results in better heat and chemical penetration, and facilitates water loss during drying, resulting in shorter drying times and better preservation of heat-labile nutrients.

In this study, fluted pumpkin leaves were thin-sliced, and dried with or without blanching, in sun light or in an oven (an electrically heated ventilated cabinet tray 
dryer) in order to determine the effect of pre-treatment and drying on their nutritive value.

\section{Materials and Methods}

A batch of fluted pumpkin freshly cut, dark green in colour leaves (about $2.0 \mathrm{~kg}$ ) was purchased.

All reagents used were analytical grade.

Preparation of leaves. Leaves were thin-sliced with a sharp knife and some of the sliced vegetable was blanched.

Blanching of leaves. For blanching, each sliced vegetable sample $(50.0 \mathrm{~g})$ was kept in a clean cheese cloth and dipped in boiling water, boiling dilute citric acid solution $(0.3 \%)$ or boiling potassium meta-bisulphite solution $(0.5 \%)$ for $10 \mathrm{~min}$. The cloth containing the vegetable was removed and gently squeezed to remove water. A total of twenty-four $(50.0 \mathrm{~g})$ samples were blanched (eight per pre-treatment). Blanched vegetable was then sun or oven dried (Rozis, 1997).

Drying of leaves. Each vegetable sample, blanched or without any pre-treatment, was spread in a thin layer on a net in a ventilated oven maintained at $60{ }^{\circ} \mathrm{C}$ as well as in a shallow tray in the sun light, at an ambient temperature of $30{ }^{\circ} \mathrm{C}$. Material was tested at intervals according to appearance and texture, with the intervals getting shorter as drying progressed. Testing interval was $5 \mathrm{~min}$ in the last $30 \mathrm{~min}$ of sun or oven drying. The time interval (to the nearest minute) from the beginning of drying to when crumbliness observed was taken as drying time (James and Kuipers, 2003). Material from each dried sample (16 subsamples from each drying condition, 4 untreated and 12 blanched; a total of 32 subsamples) was taken for determination of vitamin $\mathrm{C}$, $\beta$-carotene, protein and iron content.

Analytical methods. Moisture and protein content were determined by official methods of analysis (AOAC, 1984). Crude protein was determined by the microKjeldahl method and protein content calculated as $\mathrm{N} \times 6.25$.

For the determination of vitamin $\mathrm{C}$ content, dried and pulverised sample was extracted with $0.5 \%$ oxalic acid. Vitamin $\mathrm{C}$ in the extract was determined by coupling with 2, 4-dinitrophenyl hydrazine. Absorbance was read at $520 \mathrm{~nm}$ (Fafunsho and Bassir, 1976).

For the determination of $\beta$-carotene content, leaves were extracted using chloroform/methanol (2:1). $\beta$-carotene was determined spectrophotometrically at
$440 \mathrm{~nm}$ after ethanolic $\mathrm{NaOH}$ saponification and extraction with chloroform (Bassir, 1963). Iron content was determined by atomic absorption spectrophotometry (Novosamsky, 1983).

Statistical analysis. All analyses were done in quadruplicate and all values were expressed as mean \pm SEM. The statistical analysis was carried out using unpaired t-test and ANOVA to detect significant differences according to Ogbeibu (2005).

\section{Results and Discussion}

Three blanching treatments were employed (i) blanching of the vegetable in boiling water (which is the common practice), (ii) blanching in boiling dilute citric acid and (iii) blanching in boiling dilute potassium metabisulphite. Beneficial effect of citric acid and metabisulphite blanching on the colour of the dried product and also on the flavour and nutrient retention (in the case of citric acid), have been reported (Kendal et al., 2009; Rozis, 1997) and emphasis of this study was to observe the affect of these pre-treatments on the nutrient composition of the dried product.

Table 1 shows the effect of pre-treatment and drying conditions on the nutritional quality of fluted pumpkin leaves.

For the untreated sample, sun dried and oven dried leaves had vitamin C content of $0.967 \%$ and $1.190 \%$, respectively. Compared with the oven dried product, sun drying resulted in a loss of about a fifth (18.74\%) of this nutrient. Thus oven drying protected vitamin $\mathrm{C}$ better than sun drying. The lower value for the sundried material may have resulted from destruction of this material by ultra-violet radiation from the sun and longer drying time, which were not encountered in the oven. Leaves blanched in boiling water and sun dried had vitamin C content of $0.201 \%$; water blanched and oven dried leaves had vitamin C content of $0.177 \%$. Vitamin $\mathrm{C}$ content of leaves blanched in citric acid and sun dried was $0.161 \%$. Citric acid blanched and oven dried leaves had vitamin C content of $0.167 \%$. Leaves sun or oven dried, after blanching in dilute potassium meta-bisulphite, had vitamin C content of $0.232 \%$ and $0.169 \%$, respectively.

In all cases, leaves blanched prior to drying had lower vitamin $\mathrm{C}$ content than leaves dried without pretreatment, due to leaching of nutrients, including vitamin $\mathrm{C}$, into the blanching medium. This loss may in addition have resulted from heat denaturation of this vitamin at the blanching temperature. Compared with the untreated 
leaves, loss of vitamin $\mathrm{C}$ for the blanched and sundried leaves was $76.01-83.35 \%$ and about $85 \%$ for the oven dried leaves.

The effect of blanching and drying on the $\beta$-carotene content of fluted pumpkin leaves is shown in Table 1.

Sun and oven dried leaves had similar $\beta$-carotene content ( 9.92 and $9.63 \mathrm{mg} / \mathrm{g}$ ), respectively. Leaves blanched in boiling water followed by sun or oven drying had $\beta$-carotene content of 4.09 and $4.55 \mathrm{mg} / \mathrm{g}$, respectively. Similar values ( 4.44 and $4.58 \mathrm{mg} / \mathrm{g}$, respectively) obtained for leaves that were sun or oven dried after blanching in citric acid. However, leaves blanched in potassium meta-bisulphite followed by sun or oven drying had higher content ( 7.11 and $6.98 \mathrm{mg} / \mathrm{g}$, respectively) of this provitamin. Thus, it appears that blanching in potassium meta-bisulphite might offer better protection to the $\beta$-carotene content of the leaves than blanching in boiling water or citric acid.
The lower $\beta$-carotene content of the leaves blanched prior to drying was probably due to heat denaturation and losses from gentle squeezing of the vegetables to remove fluid before drying. Denaturation by ultraviolet radiation might also have contributed to the loss of this nutrient in the sun dried product.

Losses ranged from $28.33 \%$ to $58.77 \%$ for the sun dried and $30.63 \%$ to $52.75 \%$ for the oven dried leaves.

Effect of blanching and drying on the protein content of fluted pumpkin leaves have been shown in Table 1 .

For untreated leaves, drying gave similar protein content i.e. $10.47 \%$ for the sun dried and $10.39 \%$ for the oven dried. Leaves blanched in boiling water prior to drying had protein content of $6.07 \%$ (sun dried) and $8.77 \%$ (oven dried). Leaves blanched in dilute citric acid and sun or oven dried had protein content of $1.91 \%$ and $1.59 \%$, respectively. Leaves, sun or oven dried after

Table 1. Effect of pre-treatment and drying conditions on the nutritional contents of fluted pumpkin leaves ${ }^{\mathrm{a}}$

\begin{tabular}{|c|c|c|c|c|}
\hline Pretreatment & Sun dried & $\%$ loss & Oven dried & $\%$ loss \\
\hline & \multicolumn{4}{|c|}{ Vitamin $\mathrm{C}$ content $(\mathrm{g} / 100 \mathrm{~g})$} \\
\hline Control & $0.967 \pm 0.045$ & - & $1.190 \pm 0.036^{\mathrm{c}}$ & - \\
\hline \multicolumn{5}{|l|}{ Blanching } \\
\hline Boiling water & $0.201 \pm 0.007^{\mathrm{b}}$ & 79.21 & $0.177 \pm 0.012^{\mathrm{b}, \mathrm{c}}$ & 85.13 \\
\hline Boiling in dilute citric acid & $0.161 \pm 0.003^{\mathrm{b}}$ & 83.35 & $0.167 \pm 0.004^{\mathrm{b}, \mathrm{d}}$ & 85.97 \\
\hline \multirow[t]{2}{*}{ Boiling in dilute $\mathrm{K}_{2} \mathrm{~S}_{2} \mathrm{O}_{5}$} & $0.232 \pm 0.008^{\mathrm{b}}$ & 76.01 & $0.169 \pm 0.006^{\mathrm{b}, \mathrm{d}}$ & 85.80 \\
\hline & \multicolumn{4}{|c|}{$\beta$-carotene $(\mathrm{mg} / \mathrm{g})$} \\
\hline Control & $9.92 \pm 0.08$ & - & $9.63 \pm 0.12$ & - \\
\hline \multicolumn{5}{|l|}{ Blanching } \\
\hline Boiling water & $4.09 \pm 0.59^{\mathrm{b}, \mathrm{d}}$ & 58.77 & $4.55 \pm 0.12^{\mathrm{b}, \mathrm{c}, \mathrm{d}}$ & 52.75 \\
\hline Boiling in dil. citric acid & $4.44 \pm 0.65^{\mathrm{b}, \mathrm{d}}$ & 55.24 & $4.58 \pm 0.70^{\mathrm{b}, \mathrm{d}}$ & 52.44 \\
\hline \multirow[t]{2}{*}{ Boiling in dil. $\mathrm{K}_{2} \mathrm{~S}_{2} \mathrm{O}_{5}$} & $7.11 \pm 0.82^{\mathrm{b}}$ & 28.33 & $6.98 \pm 0.12^{\mathrm{b}}$ & 30.63 \\
\hline & \multicolumn{4}{|c|}{ Protein content ( $\%$, dry basis $)$} \\
\hline Control & $10.47 \pm 0.28$ & - & $10.39 \pm 0.33$ & - \\
\hline \multicolumn{5}{|l|}{ Blanching } \\
\hline Boiling water & $6.07 \pm 0.24^{\mathrm{b}}$ & 42.02 & $8.77 \pm 0.44^{\mathrm{b}, \mathrm{c}}$ & 15.59 \\
\hline Boiling in dil. citric acid & $1.91 \pm 0.01^{\mathrm{b}}$ & 81.80 & $1.59 \pm 0.11^{\mathrm{b}, \mathrm{c}}$ & 84.65 \\
\hline \multirow[t]{2}{*}{ Boiling in dil. $\mathrm{K}_{2} \mathrm{~S}_{2} \mathrm{O}_{5}$} & $7.48 \pm 0.12^{b}$ & 28.60 & $9.20 \pm 0.13^{\mathrm{b}, \mathrm{c}}$ & 11.40 \\
\hline & \multicolumn{4}{|c|}{ Iron content $(\mu \mathrm{g} / \mathrm{g})$} \\
\hline Control & $2.728 \pm 0.395$ & - & $2.564 \pm 0.033$ & - \\
\hline \multicolumn{5}{|l|}{ Blanching } \\
\hline Boiling water & $0.577 \pm 0.062^{\mathrm{b}}$ & 78.85 & $0.689 \pm 0.372^{\mathrm{b}, \mathrm{d}}$ & 73.13 \\
\hline Boiling in dil. citric acid & $0.894 \pm 0.075^{\mathrm{b}, \mathrm{d}}$ & 67.23 & $1.019 \pm 0.446^{\mathrm{b}, \mathrm{c}}$ & 60.26 \\
\hline Boiling in dil. $\mathrm{K}_{2} \mathrm{~S}_{2} \mathrm{O}_{5}$ & $0.732 \pm 0.033^{\mathrm{b}, \mathrm{d}}$ & 73.17 & $0.536 \pm 0.028^{\mathrm{b}, \mathrm{d}}$ & 79.10 \\
\hline
\end{tabular}


blanching in potassium meta-bisulphite had protein content of $7.48 \%$ and $9.20 \%$, respectively.

Leaves blanched prior to drying had lower protein content than those dried without pre-treatment. Leaves dried after blanching in boiling dilute potassium metabisulphite had higher protein content than leaves blanched in boiling water prior to drying. Of all the treatments, blanching in dilute citric acid prior to drying resulted in the highest protein loss. This was probably due to acid hydrolysis of protein to amino acids during blanching, and solubilisation of the latter in the blanching medium. Loss of protein after blanching and drying, ranged from $28.60 \%-81.80 \%$ for the sun dried and $11.40 \%-84.65 \%$ for the oven dried leaves indicating the presence of soluble non-protein nitrogen compounds in fluted pumpkin leaves.

The iron content of fluted pumpkin leaves from blanching and drying treatments is shown in Table 1. Untreated sundried and oven dried leaves had iron content of $2.728 \mu \mathrm{g} / \mathrm{g}$ and $2.564 \mu \mathrm{g} / \mathrm{g}$, respectively. Water blanched, sun or oven dried leaves had iron content of $0.577 \mu \mathrm{g} / \mathrm{g}$ and $0.689 \mu \mathrm{g} / \mathrm{g}$, respectively. Leaves blanched in boiling dilute citric acid prior to sun or oven drying had iron content of $0.894 \mu \mathrm{g} / \mathrm{g}$ and $1.019 \mu \mathrm{g} / \mathrm{g}$, respectively. Potassium meta-bisulphite blanched and sun dried leaves had iron content of $0.732 \mu \mathrm{g} / \mathrm{g}$; oven dried leaves had iron content of $0.536 \mu \mathrm{g} / \mathrm{g}$.

Blanched and dried leaves had lower iron content than leaves dried without pre-treatment, due to leaching of the mineral into the blanching medium. Blanching in dilute citric acid or potassium meta-bisulphite appears to have protected iron content better than blanching in boiling water. Compared with the untreated leaves, loss of iron was $67.23 \%-78.85 \%$ for the blanched and sun dried and $60.26-79.10 \%$ for blanched and oven dried leaves.
Losses in the activity of heat labile and water soluble nutrients, resulting from thermal treatment of food have been reported previously (Hotz and Gibson, 2007). However, thermal treatment, for example blanching of vegetables, can improve the bioavailability of nutrients, by destruction of antinutrients (Hotz and Gibson, 2007; Yang and Tson, 2006; Yeum and Russel, 2002; Yadev and Sehgel, 2002; Henry and Massey, 2001; RodriguezAmaya, 1997) and facilitating the release of nutrients after partial degradation of cell walls combined with protein denaturation and mineral solubilisation from fibre (Kapanidis and Lee, 1995). The effect of different blanching and drying conditions on drying time of leaves is shown in Table 2.

Untreated sundried and oven dried leaves had drying times of 235.0 and $123.0 \mathrm{~min}$, respectively. Compared to the untreated leaves, blanching in boiling water decreased drying time to $168.0 \pm 5.0 \mathrm{~min}$ for the sun dried and $80.0 \pm 4.0 \mathrm{~min}$ for oven dried leaves. Blanching in boiling dilute potassium meta-bisulphite reduced drying time to $114.0 \mathrm{~min}$ and $117.0 \mathrm{~min}$, respectively for sun dried and oven dried leaves. Blanching in citric acid decreased (for the sun dried) or increased (for the oven dried leaves) the drying time to $163.0 \mathrm{~min}$. Thus for leaves blanched in boiling citric acid or boiling potassium meta-bisulphite, drying times were similar for the sun and oven dried leaves. For leaves blanched in boiling water however, oven drying was much faster than sun drying and gave the best (i.e. shortest) drying time.

Blanching in boiling potassium meta-bisulphite gave the shortest sun drying time. Compared with the untreated leaves it shortened drying time by $51.5 \%$, but reduced oven drying time by only $4.9 \%$. Blanching in boiling citric acid shortened sun drying time by $30.6 \%$, and increased oven drying time by $32.5 \%$. Blanching in boiling water reduced sun drying time by $28.5 \%$ and reduced oven drying time by $35.0 \%$.

Table 2. Effect of pre-treatment and drying method on the drying time (min) of fluted pumpkin leaves ${ }^{a}$

\begin{tabular}{lllll}
\hline \hline Pre-treatment & Sun & \% reduction & Oven & \% reduction \\
\hline Control & $235.0 \pm 5.0$ & & $123.0 \pm 4.0^{\mathrm{c}}$ & - \\
Blanching boiling water & $168.0 \pm 5.0^{\mathrm{b}, \mathrm{d}}$ & 28.5 & $80.0 \pm 4.0^{\mathrm{b}, \mathrm{c}}$ & 35.0 \\
Boiling in dil. citric acid & $163.0 \pm 1.0^{\mathrm{b}, \mathrm{d}}$ & 30.6 & $163.0 \pm 4.0^{\mathrm{b}}$ & - \\
Boiling in dil. $\mathrm{K}_{2} \mathrm{~S}_{2} \mathrm{O}_{5}$ & $114.0 \pm 3.0^{\mathrm{b}}$ & 51.5 & $117.0 \pm 1.0^{\mathrm{b}}$ & 4.9 \\
\hline \hline
\end{tabular}

$\bar{a}=$ values are recorded as the mean of four determinations; ${ }^{b}=$ shows significant $(p<0.01)$ difference when values within the same drying method (sun or oven) exposed to different pre-treatment methods are compared with the control (no pre-treatment); ${ }^{c}$ these values were statistically different $(\mathrm{P}<0.01)$ on comparison between the drying methods after the same pre-treatment. ${ }^{d}$ using ANOVA, these values show no statistical $(\mathrm{P}>0.01)$ difference within the same drying method after different pretreatments. 
The most common culinary application of fresh or dried fluted pumpkin leaves is as an ingredient in sauces, soups and stews. This application (which involves cooking of the mixture of which the vegetable is an ingredient) would result in the destruction of antinutrients and microorganisms, and improved bioavailability without any loss of nutrients, since whatever is leached from the vegetable stays in the mixture, which is then consumed. Thus, for such application, blanching prior to drying, which results in the loss of nutrients is disadvantageous and unnecessary. If however, the dried vegetable is to be used after rehydration as an ingredient in uncooked food, for example salads, blanching is indeed necessary and confers several benefits. Blanching helps to slow enzyme activity that can cause undesirable changes in flavour and texture. In addition blanching in water or citric acid solution improves the destruction of potentially harmful bacteria during drying, including Escherichia coli 0157:H7, Salmonella species and Listeria monocytogenes (Kendal et al., 2009).

\section{Conclusion}

The effect of preservation treatments on the nutritional quality of fluted pumpkin leaves was studied. Regarding the nutrients studied, oven drying (which is more expensive) appears to confer no advantage over sun drying, except for its better preservation of vitamin C content. It however has the advantages of shorter drying time and non-dependence on the weather. Compared with the use of boiling water, blanching in boiling dilute potassium meta-bisulphite offers better protection for vitamin $\mathrm{C}, \beta$-carotene, protein and iron and shortens the sun drying time. However, citric acid blanching offers better protection than potassium meta-bisulphite for iron but results in serious loss of soluble nitrogen compounds.

\section{References}

AOAC 1984. Official Methods of Analysis. $14^{\text {th }}$ edition, Association of Official Analytical Chemists, Washington DC, USA.

Bassir, O. 1963. Handbook of Practical Biochemistry. $2^{\text {nd }}$ edition, Ibadan University Press, Ibadan, Nigeria.

Bosch, C.H., Borus, D.J., Siemonsma, J.S. 2005. Vegetables of Tropical Africa. 10 modules, 65 pp. Conclusions and Recommendations Based on PROTA 2: Vegetables. PROTA Foundation, Wageningen, The Netherlands.

Fafunsho, M., Bassir, O. 1976. Effect of cooking on the vitamin $\mathrm{C}$ content of fresh leaves and wilted leaves. Journal of Agriculture and Food Chemistry, 24: 354-376.
Henry, C.J.K., Massey, D. 2001. Micronutrient changes during food processing and storage issues. Paper 5. Crop Post Harvest Programme, DFID, Department for International Development. National Resources Institute, UK.

Hotz, C., Gibson, R.S. 2007. Traditional food processing and preparation practices to enhance the bioavailability of micronutrients in plant based diets. Journal of Nutrition, 137: 1097-1100.

James, I.F., Kuipers, B. 2003. Preservation of Fruit and Vegetables, Agrodok 3. Agromisa Foundation, Wagenigen, The Netherlands.

Kapanidis, A., Lee, T.C. 1995. Heating cruciferous vegetables increases in vitro dialyzability of intrinsic and extrinsic iron. Journal of Food Science, 60: 128-131, 141.

Kendal, P., DiPersio, P., Sofos, J. 2009. Drying vegetables. University of Colorado State University Extension Fact Sheet No. 9.308. http://www.ext. colostate.edu/pubs/foodnut/09308.html (5 August 2009).

Novosamsky, I., Houba, V.J., Eckvan, R., Varkvan, W. 1983. A novel digestion technique for multi-element plant analysis. Communications in Soil and Plant Analysis, 14: 239-249.

Ogbeibu, A.E. 2005. Biostatistics: A Practical Approach to Research and Data Handling, pp. 85-87, Mindex Publishing Company Limited, Benin City, Nigeria.

Rodriguez-Amaya, D.B. 1997. Carotenoids and food preparation: The retention of provitamin A carotenoids in prepared, processed and stored food. Opportunities in Micronutrient Intervention (OMNI), Arlington, USA.

Rozis, J.F. 1997. In: Drying of Foodstuffs. pp. 67-92, J. F. Rozis (ed.). Backhuys Publishers, Leiden, The Netherlands.

Wardlaw, G.M., Kessel, M. 2002. Perspectives in Nutrition. $5^{\text {th }}$ edition, 401 pp., McGraw Hill, New York, USA.

Wills, R., McGlasson, B., Graham, D., Joyce, D. 1998. Postharvest. An Introduction to the Physiology and Handling of Fruit, Vegetables and Ornamentals. 262 pp., $4^{\text {th }}$ edition, CAB International, Wallingford, UK.

Yadev, S.K., Sehgel, S. 2002. Effect of domestic processing and cooking methods on total, HCL extractable and in vitro availability of iron in spinach and amaranth leaves. Nutrition Health, 16: 483504.

Yang, R.Y., Tson, S.C.S. 2006. Boiling increases the iron bioavailability of vegetables. Journal of International Cooperation, 1: 107-119.

Yeum, K.J., Russel, R.M. 2002. Carotenoid bioavailability and bioconversion. Annual Review of Nutrition, 22: 483-504. 